Jurnal Manajemen dan Bisnis

Vol. 10, No. 2, December 2021, pp. 107-118

Sekolah Tinggi Ilmu Ekonomi Indragiri (STIE-I) Rengat

https://journal.stieindragiri.ac.id/index.php/jmbi/issue/view/20

\title{
ANALYSIS OF COAL EXPORT DEVELOPMENT IN ACEH PROVINCE THROUGH RCA AND MCI APPROACH
}

\author{
Khalish Khairina ${ }^{1}$, Angga Syahputra ${ }^{2 *}$ \\ ${ }^{12}{ }^{2}$ Fakultas Ekonomi dan Bisnis Islam - IAIN Lhokseumawe \\ *anggasyahputra@iainlhokseumawe.ac.id \\ Submited: 2021.08.05 Reviewed: 2021.11.20 Accepted: 2021.12.31 \\ https://doi.org/10.34006/jmbi.v10i2.290
}

\begin{abstract}
This study aims to see the development of coal exports in Aceh province using the Revealed Comparative Advantage (RCA) and Market Concentration Index (MCI) approaches. This study is a descriptive quantitative study using time series data for 6 years (2015-2020), the data taken in the form of secondary data on the value of Aceh's exports. To see the advantages of coal commodities, RCA analysis is used, while to see the spread of coal exports, MCI analysis is used. The result of this study is that the RCA value from 2015 -2019 is below 1, which means that coal from Aceh has low competitiveness. The RCA value in 2020 shows a value of 1.06, which means Aceh's coal has an advantage. The MCI value for Aceh coal always shows a number close to 1, which means that exports are not spread out and are only concentrated in one country.
\end{abstract}

Keywords: Export, Coal, RCA, MCI

\begin{abstract}
ABSTRAK
Penelitian ini bertujuan untuk melihat perkembangan ekspor batubara di provinsi Aceh dengan menggunakan pendekatan Revealed Comparative Advantage (RCA) dan Market Concentration Index (MCI). Penelitian ini merupakan penelitian kuantitatif deksriptif dengan menggunakan data time series selama 6 tahun (2015-2020), data yang diambil berupa data sekunder nilai ekspor Aceh. Untuk melihat keunggulan komoditas batubara maka digunakan analisis RCA, sedangkan untuk melihat penyebaran ekspor batubara digunakan analisis MCI. Hasil penelitian ini adalah nilai RCA dari tahun 2015 -2019 dibawah 1 yang artinya batubara asal Aceh memiliki daya saing yang rendah. Nilai RCA di tahun 2020, menunjukkan nilai 1,06 yang artinya batubara Aceh memiliki keunggulan. Nilai MCI untuk batubara Aceh selalu menunjukkan angka mendekati angka 1, yang artinya ekspor tidak tersebar dan hanya terkonsentrasi ke satu negara saja.
\end{abstract}

Kata Kunci : Ekspor, Batubara, RCA, MCI 


\section{INTRODUCTION}

Increasing the number of Gross Regional Domestic Product (GRDP) is one of the goals of a region's economic success. There are many important components that can increase the amount of GRDP, including public consumption, investment, government spending, increased real sector production and international trade. International trade which includes importexport activities can be a reliable factor to increase GRDP.

International trade consists of export and import activities. Export is the delivery of goods to a country by one country because there is a request from a buyer in that country or not (Risa, 2018). Exports have a positive and significant influence on economic growth, so to be able to encourage economic growth it takes a role and an increase in exports (Ginting, 2017). This export activity can also encourage industrialization, supply the state budget through income and foreign currency that can be used to improve infrastructure and create an attractive investment climate and encourage each country or region to increase the competitiveness of its products (Wahyuni et al., 2020). The increase in competitiveness includes product quality and product quantity exported abroad. So, in the end, export activities can spur industrial activities and drive the economy for the region or country.

Aceh, which is one of the provinces in Indonesia, has a lot of potential for exporting natural resources. To see this potential, data on the development of export activities is needed. The following picture is the development of the export value in Aceh.

Figure 1. Export Value of Aceh Province in 2011-2020 (Million USD)

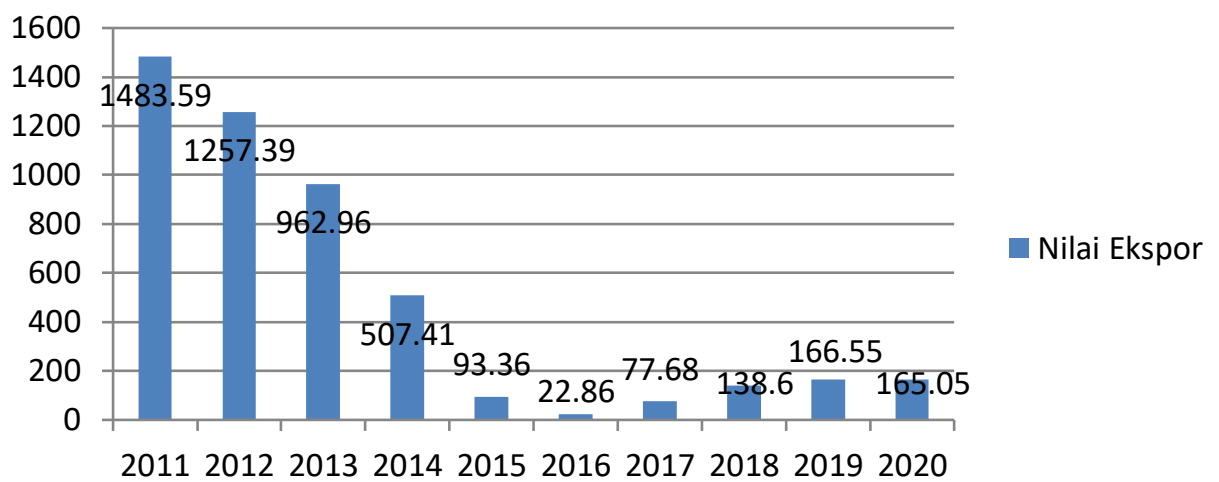

Source: (BPS Aceh, 2021)

Figure 1 shows the development of export activities in Aceh province from 2011 to 2020. Exports in Aceh over the last 10 years have shown a downward trend. From 2011 to 2016 it continued to decline. In 2016, the export value of Aceh province fell drastically to 22.86 million USD and this year is the lowest point of all Aceh's export values. From 2017 to 2019 the export value of Aceh province has increased slowly. However, in 2020, the export value decreased by 0.9 percent compared to 2019 to 165.05 million US Dollars. 
Looking at the development of Aceh's exports, there will be a decrease of 0.9 percent in 2020. If the decline occurs continuously every year, then this will affect the foreign exchange reserves of Aceh province. Export commodities are divided into two groups, namely oil and gas and non-oil and gas. The non-oil and gas group is divided into three commodity groups, namely a). agricultural product export commodities, b). export commodities resulting from the processing industry, c). export commodities from mining and others. From the data provided by the Central Statistics Agency for Aceh, export activities that contribute foreign exchange for the province of Aceh are still dominated by the non-oil and gas sector (BPS Aceh, 2021) with coal contributing 156.17 million USD, Crude Palm Oil (CPO) 5.02 million USD, and Palm Kernel Shells 1.76 million USD. The three commodities have a share of 98.73 percent of total non-oil exports, while other commodities have a share of only 1.27 percent. Coal itself has a share of $94.62 \%$ of total non-oil exports.

This high share shows that the export value in Aceh is highly dependent on the development of coal commodity exports abroad. The first quarter of 2020, there was a surge in coal production to India, which is the biggest consumer of coal from Aceh. However, in the fourth quarter of 2020, coal exports from Aceh to India experienced a drastic decline. This is because of the COVID-19 pandemic that has hit the whole world. This pandemic has caused export destination countries to close their port doors due to the lockdown regulations. As a result, the distribution of goods and services was disrupted which in the end due to this regulation caused the demand for coal from Aceh to also decline.

Apart from the COVID-19 pandemic, coal exports from Aceh are highly dependent on demand from India and China. So if there is a decrease in demand or there are obstacles given by the two countries to coal commodities from Aceh. Then the export value of Aceh province will also experience a very drastic decline as well. Considering the share value of coal which is $>90 \%$ of the total value of Aceh's exports. In international trade activities, the value and amount of exports can be influenced by internal and external conditions. These internal conditions can be in the form of infrastructure conditions, competitiveness of products or commodities, the business environment, and the role of the government. Meanwhile, external conditions can be in the form of global economic conditions (Multazam et al., 2019). Thus, this study aims to see the development of exports (internal conditions) of coal commodities from Aceh by using the RCA and MCI analysis approaches. The RCA analysis is used to see the development of exports in terms of the competitiveness of Aceh's coal commodities for 6 years (2015 - 2020), while the MCI analysis is used to analyze the vulnerability of Aceh's coal export commodities for 6 years (2015 -2020). 


\section{METHODOLOGY AND DATA}

This type of research is a quantitative descriptive analysis. The data used in this study is secondary data (time series), in the form of data on the value of Aceh's coal exports for 6 years (2015-2020) and data on the distribution of Aceh's coal export values for 6 years (20152020) which can be accessed on the Aceh BPS (Central Statistics Agency) website with the title of publication of Aceh Foreign Trade Statistics 2020.

The analytical method used to see the development of exports in terms of competitiveness, the authors use the Revealed Comparative Advantage (RCA) analysis, while the Market Concentration Index (MCI) analysis is used to see the development of exports in terms of the distribution of coal commodities to all export destination countries which aims to see how vulnerable the export commodity is.

\section{a. Revealed Comparative Advantage (RCA)}

Reducing barriers in international trade causes countries to compete and develop technology in order to increase the amount of production. Comparative advantage is a term used to describe a country's ability to export commodities that produce relatively more than other countries (Serin \& Civan, 2008). The main determining factor for success in comparative advantage is the number of natural resources and human resources capable of producing large volumes/productions (Wulandari \& Lubis, 2019)

Several literatures have used RCA measurement to measure comparative advantage. Revealed Comparative Advantage (RCA) is one of the theories developed by Ballasa which uses country export data to determine the export pattern of industrialized countries from 1953 to 1971 (Batra \& Khan, 2005). RCA can be used to measure the level of competitiveness of export commodities owned by a country (Fertö \& Hubbard, 2003). In the context of international export specialization, the RCA measurement shows a strong focus on several real sectors of a country (Laursen, 2015). The rationale underlying this method is that a country's export performance is largely determined by its level of competitiveness relative to similar products made in other countries, of course with the assumption (cateris paribus) that other factors affecting export growth remain unchanged (Bustami \& Hidayat, 2013 ). RCA results can also be used to evaluate changes that occur due to trade barriers and help identify which countries are competitors in a perfectly competitive market (French, 2017). Here's the general formula for calculating RCA:

$$
R C A=\frac{X i / X t}{W i / W t}
$$




$$
\text { Dimana : } \begin{aligned}
& \mathrm{Xi}=\text { export value of a region for sub-sector } \mathrm{i} \\
& \mathrm{Xt}=\text { the total value of a region's exports } \\
& \mathrm{Wi}=\text { value of country exports for sub-sector } \mathrm{i} \\
& \mathrm{Wt}=\text { the total value of a country's exports }
\end{aligned}
$$

If the RCA value $<1$ then this indicates the commodity has low competitiveness. On the other hand, if RCA > 1, it indicates that the commodity has high competitiveness.

\section{b. Market Concentration Index (MCI)}

The Market Concentration Index or more often referred to as the Market Concentration Index is one of the methods used to see the export strength of a commodity from the buyer's point of view. This method has become the most popular indicator for measuring market concentration due to its very simple measurement method (Krivka, 2016). This analysis tool serves to see the vulnerability of a commodity. If the export of a commodity is only concentrated in one country, the commodity is very vulnerable to the crisis of that country. On the other hand, if the export commodities spread to various countries, the less likely the commodity will be hit by a crisis (Yusuf, 2012).

$$
M C I=\sqrt{\left(\frac{X i}{\sum X}\right)^{2}}+\left(\frac{X i 2}{\sum X}\right)^{2}+\ldots . .+\left(\frac{X n}{\sum X}\right)^{2}
$$

Where: $\mathrm{Xi}, \mathrm{Xi} 2, \mathrm{Xn}$ are the export value of commodity i to other countries

$\sum \mathrm{X}$ is the total export value of commodity $\mathrm{i}$ to all over the world

The MCI value is between 0 and 1 , the closer to 0 the MCI value is better because it means exports are more spread out.

\section{RESULTS AND DISCUSSION}

\section{a. Aceh Province Export Development}

Aceh Province is one of the provinces that has its own uniqueness compared to other provinces in Indonesia. Aceh was given special authority in managing its region. In Law no. 44 of 1999, Aceh received four privileges, namely the provision of education, religious life, traditional life, and the role of ulama in regional policy making. Aceh, with a Muslim majority as its population, always puts forward Islamic principles in every economic activity, including international trade. International trade is trade that occurs between countries that cross borders between countries. International trade in Islam is allowed, because there is no evidence that forbids it. International trade in Islam is allowed as long as it does not sell illicit goods and there is a clear trade agreement (Hendang Waluya, 2016). 
Based on data accessed from the Central Statistics Agency for Aceh, the export value of Aceh province has fluctuated over the last 10 years. This can be seen in the following table:

Table 1. Aceh Province Foreign Trade 2011 - 2020 (USD)

\begin{tabular}{|c|r|r|r|}
\hline YEAR & $\begin{array}{c}\text { EXPORT } \\
\text { VALUE }\end{array}$ & $\begin{array}{c}\text { IMPORT } \\
\text { VALUE }\end{array}$ & \multicolumn{1}{c|}{$\begin{array}{c}\text { BALANCE OF } \\
\text { TRADE }\end{array}$} \\
\hline 2011 & 1.483 .590 .754 & 114.045 .379 & 1.369 .545 .375 \\
\hline 2012 & 1.257 .398 .628 & 85.316 .413 & 1.172 .082 .215 \\
\hline 2013 & 962.969 .640 & 11.130 .170 & 951.839 .470 \\
\hline 2014 & 507.414 .478 & 40.515 .391 & 466.899 .087 \\
\hline 2015 & 93.336 .621 & 116.817 .672 & -23.481 .051 \\
\hline 2016 & 22.869 .514 & 28.994 .572 & -6.125 .058 \\
\hline 2017 & 77.679 .139 & 39.313 .804 & 38.365 .335 \\
\hline 2018 & 138.628 .891 & 29.690 .002 & 108.938 .889 \\
\hline 2019 & 166.556 .778 & 131.223 .684 & 35.333 .094 \\
\hline 2020 & 165.053 .771 & 26.051 .364 & 139.002 .407 \\
\hline
\end{tabular}

Source : (BPS Aceh, 2021)

In 2012 there was a decline in the value of Aceh's exports compared to 2011. Likewise with Aceh's trade balance. Although Aceh's trade balance has decreased, the trade balance is still in a surplus. In 2013 the export value of Aceh was 962.97 million USD. This value decreased by 23.42 percent compared to the previous year of 1.26 billion USD. During the period 2011-2013 the highest export value occurred in 2011, while the lowest export value occurred in 2013. In 2013 Aceh's oil and gas exports amounted to 929.80 million USD and non-oil and gas exports amounted to only 33.17 million USD. During the last three years, Aceh's export development has been highly dependent on oil and gas commodities. Meanwhile, non-oil and gas commodities only have a small contribution to the total exports of Aceh Province.

In 2014 Aceh's export value was 507.41 million USD. This value decreased by 47.31 percent compared to the previous year. In 2014, Aceh's exports were dominated by the oil and gas sector. The export value of Aceh has decreased due to the decline in the selling value of oil and gas. This change in the value of oil and gas commodities has caused a decline in the export value of Aceh province. Furthermore, in 2015 there was a drastic decline in the value of Aceh's exports because oil and gas commodities were not available in Aceh province, while the non-oil and gas sector could not replace the oil and gas sector. This causes the trade balance to experience a minus. In 2016 the export value of Aceh was 22.87 million USD. Aceh's export value decreased by 75.49 percent compared to the previous year, which was 93.34 million USD. When compared to 2012, Aceh's export value decreased by 98.18 percent. During the period 2012-2016 the highest export value occurred in 2012, while the lowest export value occurred in 2016. In 2016, there were no oil and gas exports from Aceh Province, but non-oil exports amounted to 22.87 million USD. So far, Aceh's export development has been highly dependent on oil and gas commodities, but since 2016 the value 
of exported oil and gas commodities has been nil due to the absence of oil and gas commodities in Aceh so that Aceh's exports depend on non-oil and gas commodities.

In 2017 the export value of Aceh was 77.68 million USD. This value has increased by 239.67 percent compared to the previous year. In 2017, the value of non-oil and gas exports was 77.68 million USD. In 2018, Aceh's export value was 138.63 million USD. This value has increased by 78.46 percent compared to the previous year. The non-oil and gas sector, which is dominated by coal commodities, contributes a large proportion of the total export value of Aceh Province. In 2019, the export value of Aceh province was 166.56 million USD. This value has increased by 20.15 percent compared to 2018. In 2020, the value of exports through ports in Aceh is USD 165.05 million. Aceh's export value decreased again by 0.9 percent compared to the previous year. This is due to the COVID-19 pandemic which has caused almost all countries to implement a lockdown policy.

\section{b. Coal Export Product Development Through RCA Approach}

In 2011 to 2014 the oil and gas sector contributed the largest export value to the total export value of Aceh province. In 2015, oil and gas commodities are no longer available. Thus, in 2015 the non-oil and gas sector became the only foreign exchange contributor for the Aceh region. From a period of 6 years, the export value of Aceh province has increased slowly. The largest non-oil and gas export commodity is Coal, whether or not pulverised, but not agglomerated, other coal (coal), followed by Crude Palm Oil (CPO), and Palm Kernel Shells (palm skin) as the third largest commodity. These three largest commodities account for $>90 \%$ of the total export value in Aceh.

In 2015, the non-oil and gas sector began to become the only foreign exchange earner for the province of Aceh. Coal commodities provide a share of $23.50 \%$ this year. Furthermore, in 2016, the share of this commodity decreased to $19.34 \%$. In 2017, the export value of coal commodities was 66.76 million USD. The export value of this coal commodity contributed a share of 85.94 to the total export value of Aceh. In 2018 - 2019 the total export value of coal commodities continued to increase, and contributed a share of $>90 \%$ of the total export value of Aceh. In 2020, coal commodities have a share of 94.62 percent of total non-oil exports of 156.17 million USD. This can be seen in the following table:

Table 2. Development of Coal Commodity Export Value

\begin{tabular}{|c|c|c|}
\multicolumn{2}{c|}{ Year 2015 -2020 (USD) } \\
\hline Year & $\begin{array}{c}\text { Coal } \\
\text { Commodity } \\
\text { Export } \\
\text { Value }\end{array}$ & $\begin{array}{c}\text { Total Value } \\
\text { of Aceh's } \\
\text { Exports }\end{array}$ \\
\hline 2015 & 21.934 .647 & 93.336 .621 \\
\hline
\end{tabular}




\begin{tabular}{|l|r|r|}
2016 & 4.422 .195 & 22.869 .514 \\
\hline 2017 & 66.757 .785 & 77.679 .139 \\
\hline 2018 & 129.628 .026 & 138.628 .891 \\
\hline 2019 & 154.531 .102 & 166.556 .778 \\
\hline 2020 & 156.171 .214 & 165.053 .771 \\
\hline
\end{tabular}

Source: (BPS Aceh, 2021)

Table 2 shows the export value of coal commodities over the last 6 years. There is a trend of increasing the export value of coal commodities. Coal, which is a non-oil and gas commodity, the largest contributor to foreign exchange for the province of Aceh, needs to be analyzed for its comparative advantage using RCA analysis. The results of the calculation of RCA for coal commodities can be seen in the following table:

Table 3. Development of Aceh and Indonesia's Coal Export Value (USD), and Calculation of RCA for Aceh's Coal Exports

\begin{tabular}{|c|c|c|c|c|c|}
\hline Year & $\begin{array}{c}\text { Aceh's } \\
\text { Coal } \\
\text { Export } \\
\text { Value }\end{array}$ & $\begin{array}{c}\text { Aceh's } \\
\text { Total } \\
\text { Export } \\
\text { Value }\end{array}$ & $\begin{array}{c}\text { Indonesian } \\
\text { Coal Export } \\
\text { Value }\end{array}$ & $\begin{array}{c}\text { Total Export } \\
\text { Value of } \\
\text { Indonesia }\end{array}$ & RCA \\
\hline 2015 & 21.934 .647 & 93.336 .621 & 1.471 .700 .000 & 1.503 .663 .000 & 0,24 \\
\hline 2016 & 4.422 .195 & 22.869 .514 & 1.291 .400 .000 & 1.451 .340 .000 & 0,22 \\
\hline 2017 & 66.757 .785 & 77.679 .139 & 1.787 .700 .000 & 1.688 .282 .000 & 0,81 \\
\hline 2018 & 129.628 .026 & 138.628 .891 & 2.063 .140 .000 & 1.800 .127 .000 & 0,82 \\
\hline 2019 & 154.531 .102 & 166.556 .778 & 1.895 .720 .000 & 1.676 .830 .000 & 0,82 \\
\hline 2020 & 156.171 .214 & 165.053 .771 & 1.453 .400 .000 & 1.631 .910 .000 & 1,06 \\
\hline
\end{tabular}

Source: (BPS Aceh, 2021) processed data.

Based on table 3, in 2015, the export value of Aceh's coal was 21.93 million USD. With the results of the RCA calculation of 0.24 which means that the competitiveness of Aceh's coal exports is still low. This year, the total value of Aceh's exports experienced a drastic decline due to changes in the main export commodity in the form of oil and gas. So that the total value of Aceh's exports also shifts to the non-oil and gas sector. This year, Aceh's exports depend on the non-oil and gas sector. The value of coal exports is the second largest contributor to the total value of Aceh's exports.

In 2016 , the value of coal exports decreased by $20.16 \%$ from the previous year. So that the value of the RCA calculation also decreased to 0.22 , which means that coal commodities still have low competitiveness. In 2017, there was an increase in the calculation of the RCA for coal commodities, to 0.81 . This figure is almost close to 1 , but it is still categorized as coal commodity from Aceh which still has low competitiveness. In 2017, the value of Aceh's exports slowly shifted to the non-oil and gas sector. This year, the value of coal exports has increased, and is the main largest contributor to the total value of Aceh's exports. 
In 2018 and 2019 there was an increase in the value of coal exports. In these two years, the value of coal exports is also the largest contributor to the total value of Aceh's exports. However, the calculation of RCA in these two years still shows a value below 1, which is 0.82. Even though it is close to 1 , it is still categorized as a commodity that has low competitiveness.

In 2020, there will be an increase in the production and value of Aceh's coal exports. Although in the fourth quarter there was a decline in export volume, at the beginning of the first quarter coal exports were abundant. In 2020, the calculation result of RCA for coal commodity is 1.06. This figure shows that coal from Aceh has strong competitiveness. Based on the results of this RCA calculation, coal commodity can be used as a leading export commodity. Coal commodity in Aceh is a commodity with abundant production. In 2020, despite the COVID-19 pandemic that hit the whole world, coal production and coal export value in Aceh remained high. At the end of 2020, many countries implemented lockdown policies, and of course this policy disrupted the smooth distribution of export goods. In 2020, coal production in Indonesia itself experienced a decline, but this did not happen in the province of Aceh. The results of the RCA calculation which show a value of 1.06 can already prove that coal commodity from Aceh can be used as a superior commodity as a foreign exchange contributor for Aceh.

\section{c. Coal Export Product Development Through MCI Approach}

Market Concentration Index is one of the methods used to see the distribution of an export commodity. This analysis is used to see if a commodity is spread out or only depends on one country. If the MCI value is close to 0 then the better, which means that the commodity is more spread out.

Table 4. Distribution of Aceh's Coal Export Value to Various Countries

\begin{tabular}{|c|c|c|c|c|c|c|c|}
\hline Year & $\begin{array}{c}\text { Total Coal } \\
\text { Export } \\
\text { Value }\end{array}$ & China & Thailand & Malaysia & Vietnam & India & MCI \\
\hline 2015 & 21.934 .647 & - & - & 165.113 & - & 21.769 .534 & 0,99 \\
\hline 2016 & 4.422 .195 & 1.019 .297 & - & - & - & 3.402 .898 & 0,80 \\
\hline 2017 & 66.757 .785 & 23.075 .654 & 1.500 .400 & - & - & 42.181 .731 & 0,72 \\
\hline 2018 & 129.628 .026 & 23.835 .116 & 17.823 .869 & - & - & 87.969 .041 & 0,72 \\
\hline 2019 & 154.531 .102 & 5.862 .782 & 11.630 .789 & - & 2.611 .500 & 134.426 .031 & 0,87 \\
\hline 2020 & 156.171 .214 & 2.011 .158 & 11.584 .812 & - & 16.046 .938 & 126.528 .306 & 0,82 \\
\hline
\end{tabular}

Source: (BPS Aceh, 2021) data processed.

Table 4 shows the distribution of Aceh's coal exports to various countries and the calculation of the MCI analysis. In 2015, Aceh's coal exports were only exported to two 
countries, namely Malaysia and India. This causes the MCI calculation level to almost touch the number 1, which is 0.99. This figure shows that the export of vulnerabilities vulnerabilities. If India experiences a crisis or stops coal imports from Aceh, it will have a huge impact on coal exports from Aceh. In 2016, the MCI values showed improvement to 0.80. This year, coal exports spread to India and China.

In 2017 and 2018 the MCI calculation became 0.72. In the past two years, coal exports have spread to three countries, namely India, Thailand and China. Meanwhile, India is the largest consumer of coal exports from Aceh. In 2019, the MCI calculation increased to 0.87. It is intended that coal exports are only for one area. This year, exports spread to four countries, namely China, India, Vietnam and Thailand. Although the export destination has increased, it imposes a desire for a country, namely India.

In 2020, demand for coal exports by India, China, and Thailand decreased. This is due to the COVID-19 pandemic which has caused the country to implement a lockdown policy, thus disrupting the distribution of coal exporters. Nevertheless, there was an increase in the value of coal exports from Vietnam. This causes the MCI calculation to improve to 0.82 . MCI figures still show that the spread of coal exports still shows a country, but it was better the previous year.

Based on the calculation of RCA and MCI, coal exports from Aceh must be improved in quality and the destination of coal exports must be spread out. Based on RCA calculations, each year shows the direction of improvement. In 2020, the RCA value has reached 1.06 which shows that it has an advantage. This is good, but the province of Aceh must evaluate to improve the competitiveness of coal in the following years. To increase the competitiveness of coal exports, there are several things that can be done by Aceh, namely by increasing research and development of coal, improving facilities and infrastructure, roads and electricity so that distribution flows can run smoothly.

Meanwhile, if you look at the MCI calculation, the MCI value is always close to 1 . This is an indicator for the Aceh province to improve this in order to avoid dependence on export destinations. From the last 6 years, Aceh's coal exports have been highly dependent on India. So that if India stops coal exports, it will greatly affect the decline in the value of Aceh's coal exports.

To overcome this, the province is advised to increase the value of its exports by looking for new export countries. This is intended if the export destination market is to be achieved by cooperation, then there are already other export destinations. The search for this new export destination can be done with market research, market visits to trade exhibitions to the country. China and other countries can be the main destinations for coal exports. Even though China 
has high coal production, China's domestic demand for coal is still lacking. Thus, the Aceh provincial government can take advantage of this opportunity to make China one of the other export destination countries. To make China the next export destination, there are several strategies that can be done, namely; Maximizing the production of low and medium calorie coal specifically for export to China, producing coal according to the quota set by the Government so that coal prices do not fall and conducting mergers with small-scale coal mining companies (Wibowo, 2019). This strategy can be used as input so that Aceh's coal exports are not only dependent on India, but can also be spread to various countries.

\section{Conclusion}

Based on the calculation results of RCA and MCI, it can be concluded that coal commodities have competitiveness for export to other countries. Meanwhile, by looking at the results of the MCI calculation, Aceh's coal exports are only concentrated in one country. This can be seen from the MCI value which is close to 1 .

Some suggestions that can be considered are the results of this research to increase and develop coal exports in Aceh, there are several strategies that can be carried out, namely, first, conducting market research to develop coal products, Second, improving infrastructure and infrastructure in coal transportation, Third, reducing dependence on export destination markets, by establishing cooperation with other potential and new export destination markets. Fourth, produce coal according to the quota, this is done so that coal prices do not fall.

\section{REFERENCES}

Batra, A., \& Khan, Z. (2005). Revealed Comparative Advantage: an Analysis for India and China. ICRIER Working Paper, 91. https://www.econstor.eu/bitstream/10419/176190/1/icrier-wp-168.pdf

BPS Aceh. (2021). Statistik Perdagangan Luar Negeri Aceh (Koordinator Fungsi Statistik Distribusi (ed.)). Badan Pusat Statistik Aceh.

Bustami, B., \& Hidayat, P. (2013). ANALISIS DAYA SAING PRODUK EKSPOR PROVINSI SUMATERA UTARA. Jurnal Ekonomi Dan Keuangan, 1(2), 14876. https://media.neliti.com/media/publications/14876-ID-analisis-daya-saing-produkekspor-provinsi-sumatera-utara.pdf

Fertö, I., \& Hubbard, L. J. (2003). Revealed Comparative Advantage and Competitiveness in Hungarian Agri-Food Sectors. World Economy, 26(2), 247-259. https://doi.org/10.1111/1467-9701.00520

French, S. (2017). Revealed comparative advantage: What is it good for? Journal of International Economics, 106, 83-103. https://doi.org/10.1016/J.JINTECO.2017.02.002

Ginting, A. M. (2017). ANALISIS PENGARUH EKSPOR TERHADAP PERTUMBUHAN EKONOMI INDONESIA. Buletin Ilmiah Litbang Perdagangan, 11(1), 1-20. https://doi.org/10.30908/BILP.V11I1.185

Hendang Waluya, A. (2016). Perdagangan Internasional dalam Islam. In Majalah Tabligh (Vol.

4, Issue 14 ,

p. 
https://www.academia.edu/34138213/Perdagangan_Internasional_Dalam_Islam_pdf

Krivka, A. (2016). On the Concept of Market Concentration, the Minimum HerfindahlHirschman Index, and Its Practical Application. Panoeconomicus, 63(5), 525-540. https://doi.org/10.2298/PAN140407025K

Laursen, K. (2015). Revealed comparative advantage and the alternatives as measures of international specialization. Eurasian Business Review 2015 5:1, 5(1), 99-115. https://doi.org/10.1007/S40821-015-0017-1

Multazam, M., TN., A. Z., \& Budiarto, B. (2019). PERKEMBANGAN EKSPOR NONMIGAS INDONESIAPERIODE 2012-2016. CALYPTRA, 7(2), 4316-4325. https://journal.ubaya.ac.id/index.php/jimus/article/view/3741

Risa, M. (2018). Ekspor Dan Impor - Mey Risa - Google Buku (Pertama). Poliban Press. https://books.google.co.id/books?id=DY2IDwAAQBAJ\&printsec=frontcover\&hl=id\&so urce $=$ gbs_ge_summary_r\&cad $=0 \# v=$ onepage $\& \mathrm{q} \& \mathrm{f}=$ false

Serin, V., \& Civan, A. (2008). Revealed Comparative Advantage and Competitiveness : A Case Study for Turkey towards the EU. Researchgate.Net, 10(January 1995), 25-41. https://www.researchgate.net/profile/Abdulkadir-

Civan/publication/242419012_Revealed_Comparative_Advantage_and_Competitiveness _A_Case_Study_for_Turkey_towards_the_EU_Competitiveness_of_Turkish_Fruit_and_ Vegetable_Sectors_in_EU_Market/links/56b8701008ae3c1

Wahyuni, I. P., Amir, A., \& Nurjanah, R. (2020). Hubungan kausalitas ekspor batubara dengan pertumbuhan ekonomi Provinsi Jambi. E-Journal Perdagangan Industri Dan Moneter, 8(1), 23-30. https://doi.org/10.22437/PIM.V8I1.7617

Wibowo, G. C. A. (2019). Strategi Meningkatkan Pangsa Pasar Tiongkok Menjadi Negara Tujuan Utama Ekspor Batubara Indonesia 2004 -2019. Ejournal-Uksw-Ecodunamika, 3(2). https://ejournal.uksw.edu/ecodunamika/article/view/4140

Wulandari, S., \& Lubis, A. S. (2019). Analisis Perkembangan Ekspor Impor Barang Ekonomi di Provinsi Sumatera Utara. Jurnal Administrasi Bisnis, 8(1), 31-36. https://doi.org/10.14710/JAB.V8I1.22403

Yusuf, M. (2012). Ilmu Ekonomi Regional (Pertama). Perdana Publishing. 